\title{
文化財庭園保存修理における設計監理者の役割について
}

\section{The Role of Designer for Garden Repairs as Cultural Properties}

\section{吉村 龍二 YOSHIMURA, Ryuji}

株式会社環境事業計画研究所 Institute of Environmental Program and Plan Inc.

Key Words : 1. 設計監理者

2. 文化財庭園修理

3. 文化財庭園保存管理技術

\section{はじめに}

現在、国指定の名勝庭園は 200 個所近くあり、その一 部において、保存修理事業が行われている。

本報告は、文化財庭園保存修理における設計監理者の 求められる役割（職務内容）について、6 つのカテゴリ 一の分類し、私見をまとめたものである。

\section{1．文化財庭園修理事業のアウトライン設定}

文化財庭園の修理は、日常庭園管理の中でおこなわれ る小修理とある周期で行われる大修理に大別することが できる。この文化財庭園修理事業は、主にある周期（概 ね 30 年前後)で行われる大修理の際に行われるものであ り、これまで数多くの文化財庭園において行われてきた。 しかしながら、これまでの修理事業は、小修理の延長線 上として扱っていのものが多く、顕在化した庭園の毁損 についてどのように対処するかということが主眼であっ たと言えるのではないだろうか。この場合、各論に捉わ れてしまい庭園全体についての評価がおろそかになり、 現時点で取り扱わないといけない優先順位の高い問題点 を先送りしている可能性がある。そのため文化財庭園修 理事業を行う場合、修理工事着手前において事業内容の 見立てをすることが必要である。この見立てが、文化財 庭園保存修理事業の基本計画並びに保存管理計画に該当 するものであり、その中で、修理の必要箇所を列挙し、 その対策を記載し、優先順位を付忛、必要事業予算を算 出し、事業の年次工程計画を作成するもので、文化財庭
園保存修理事業のアウトラインを記載したものである。 このアウトラインを作成することによって、“何が必要 なのか’など関係者の共通認識を得るものである。これ らの内容は、学識経験者や専門家、関係者などで組織す る委員会を設置し、その具体的内容について審議しなが ら策定している場合が多く、客観性のある合議性て策定 している。このアウトラインの作成を行うことが設計監 理者の役割の一つである。

\section{2. 調查編}

文化財庭園保存修理における調査は、発掘調查、現況 調查、資料調査の3つに区分することができる。この調 查成果内容の良否が直接修理内容に影響を及ぼし、修理 をどこまで行ってよいかなどの幅を判断する根拠となる ため、最も基本的で重要な項目である。

(1) 発掘調查

近年、発掘庭園の検出や文化財庭園修理事業の修理事 例が増加し、また埋蔵文化財研究技術の進歩などから、 生きた遺構と捉えられる文化財庭園の構造などの内容が 明らかになりつつある。庭園における発掘調查は、現在 の庭園意匠 (構造) に変遷の有無やその構造の工法につ いて明らかにすることを目的として行うものである。し かし、庭園の発掘は、微細な土層の区分を要求し、他事 例を把握した状況からの知見に基づいた類推を必要とす ることから極めて専門的な技術である。庭園設計監理者 は、庭園発掘技術者と発掘成果を見ながらそれぞれの知 
見に基づき内容を協議し、合同で所見の作成を行う。ま た、調查個所の設定については、庭園修理内容と直接関 係することから、設計監理者が設定することが望ましい。

\section{(2) 現況調査}

設計監理者が専門分野の協力を経ながら担当する事項 で、大きく実測図作成と構成要素調査に区分される。

(i) 実測図作成

文化財庭園修理の一番基本となる資料で、庭園の概要 を表わすものである。この測量罒がこれまで多く作られ てきた庭園においては、庭園の変遷が図面を比較寸るこ とによって半明することから、大修理を行う保存修理事 業毎に作成することが望ましい。庭園の実測図は、土木 の測量図とは異なり、記号表示ではなく、写実的に記載 し、庭園の様子が把握できることが重要である。

(ii) 構成要素調査

池や流れなどの水系施設や園路などの構造物、庭園樹 木などの植栽、灯篭や蹲などの石造美術品、垣や門など の工作物、建造物など庭園はさまざまな構成要素で成り 立っている。それらの構成要素について、修理履歴や変 遷、構造、毁損度などを調査し、修理の必要性などにつ いて検討守る。

(3) 資料調查

設計監理者が専門分野の協力を経ながら担当する事項 で、大きく資料・文献調査と聞き取り調査に区分される。 資料調查は、時閒が経過すると収集困難になる可能性が。 あることから、現時点において可能な限り記載すること が望ましい。

\section{(i) 資料・文献調查}

古文書や絵図などの庭園に関する資料を収集し、庭園 の成り立ちや変遷を追求する。特に現地における文化性 の理解や資料収集力などから、その地域の文化財担当者 の協力を得ることが望ましい。また、古写真なども庭園 の変遷（特に植栽が繁茂し景観が変化した状況に適す） を検討する資料となることから、極力多く収集する必要 がある。

\section{(ii) 聞き取り調查}

庭園の変遷並びに管理状況を把握するために行うもの であり、新・旧所有者や管理者から、庭園の内容につい て受け継いできた事柄についてヒアリングを行う。保存 管理計画の場合、管理計画を策定する場合には、特に管
理者からのヒアリングは、基礎となる項目であることか ら十分行う必要がある。

\section{3. 計画編}

前述 1 の文化財庭園修理事業のアウトライン設定と同 様であるが、前者は、事業着手前の概要を設定するとい う側面で女り、この計画編においては、前述 2 の調査編 に基づいて行われる計画を対象としている。

\section{(1) 庭園修理基本計画}

毀損のある庭園を修理するために作成する計画書で、 主に庭園の概要、調查内容 (発掘調査、現況調査、資料 調查)、修理計画（修理方針、修理対象選定、年次計画、 予算計画）を行うものである。

\section{(2) 庭園保存管理計画}

庭園を優良に維持管理し、保存継承するための指針を 策定するもので、整備計画を有するものは修理を伴うも のである。

\section{(i ) 整備計画}

上記基本計画の内容とほぼ同様であり、庭園の沿革や 歴史、庭園の現況、修理計画（公開活用に伴う施設整備 を含む）を行うものである。

(ii) 管理計画

庭園を優良に維持管理するために必要な、管理指針や その管理に必要な体制整備などの計画を行うものである。

\section{4. 設計編}

通常の実施設計は、不確定要素が少なく、設計図通り に施工すれば、概ね目的のものが完成するものであるが、 文化財庭園修理の実施設計は、発掘調查や現況調査の成 果など限られた情報の中で想定し、作成していることか ら、実際とは異なることが多く、目的のものが完成する とは限らない。それは、文化財庭園が生きた遺構である ことが影響している。発掘庭園以外の現存庭園は、先行 して全面発掘を行い全体の内容を検証したうえで設計が できないことから、設定する調查区がその庭園を代表す るものであるのかが判断できないことに起因する。その ため、設計においては、如何に柔軟に対応できる状態に 設定するかが重要であり、そのためには、様々な局面に 対応できる専門的知識学有する技術者がいる体制が可能 な設計が重要である。以下に、設計における 2 区分の設 
計図の作成と積算について記載する。

\section{(1) 実施設計図の作成}

前述のように設計図は、現実と異なることが多く、実 施設言十段階では、施工範囲と基本構造を明記する程度と 考えるのが現実的である。修理工事老行う過程で、埋蔵 文化財担当者の立会を得、指導委員や経験豊富な施工者 と協議しながら構造を確定していくこととなる。そのこ とから、特記仕様書に、(1)柔軟に変更することや埋蔵文 化財や委員、関係者の指導を得、進めること。(2)文化財 庭園保存技術を有古古文化財庭園保存技術者協議会会員 の協力を得ること。(3)材料の変化や工法の廃絶など、現 構造を再現するために必要な、試験や工法の追及を行う こと。(4)修理内容においては、設計監理者と十分に協議 し行うこと。の以上 4 項目を記載することが必要である。

\section{(2) 工事費算出}

文化財庭園の修理は、極めて専門的で高度な技術を要 し、文化財として扱う必要があることから手閒がかかり、 また、遺構状況によって工法が変化し、手間も異なるこ とから公園新設における公共歩掛りで対応することは困 難で現実的ではない。さらに、繁茂した植栽景観を作庭 意図が理解できる植栽景観に戻す必要がある場合、その 剪定作業も、樹木のほとんどを剪定するものや枝 1 本の 場合もあり、かつその作業は、ある視点場から状況を判 断しながら決定していくものなので、あらかじめ想定す ることは難しく、基本剪定や軽剪定しか公共歩掛りでは、 やはり刘応することは現実的ではない。また、実施設計 の内容も前述の通り、漠とした状況であることから、全 体として造園工を何人として設定するかという程度で対 応することが望ましいと言える。

\section{5. 設計監理編}

設計監理については、修理工事における設計監理と修 理工事終了後に発行する報告書作成の 2 つに分される。 (1) 設計管理

前述 4 の設計での記載通り、文化財庭園の修理は、当 初の実施設計図書に記載されている内容で完結できるこ とは少ない。修理する段階になって、石を取り外し初め て全体が確認できる状態であり、これまでの想定とその 遺構状況を関係者（指導委員、埋蔵文化財担当者、行政 担当者、庭園研究者、施工者、設計監理者）にて協議し
し、施工方法を決定していく。設計監理者はそれぞれの 意見を集約、調整し、修理施工を進め、その修理に到る プロセスを記録寸る。変更が生じた場合、設計変更を行 い、今後の文化財庭園修理における設計指針構築のため の基礎資料とする必要があると考える。

\section{（2）修理報告書作成}

文化椇庭園の大修理は、概小30年前後で1度行われる。 これまでの修理事業において修理報告書が発行されてい ないものが多く、その後に再度修理事業を行うときに、 前回の修理内容が的確に把握できないと、修理方針を誤 る可能性がある。今後の文化財庭園修理においては、必 ず修理報告書を発行し、現時点で収集可能な資料を取り まとめるとともに、今回の修理内容（修理指針）を記載 し、今後の修理事業の基礎資料とする。

\section{6. マネジメント編}

設計監理者は、特に事業者が個人などの場合、文化財 庭園修理事業を運営することも重要な役割である。その 3つの大きな内容を以下に記載する。

\section{(1) 事業主体者の代理}

現状変更や交付申請などの書類作成や事業主体者に変 わり、事業内容を説明することなどの事業者代理人とし ての役割堂行う。

\section{(2) 委員会の運営}

委員会資料の作成や説明などの運営を行う。

\section{(3) 事業体制づくり}

内容に応じて、専門家を召集し、つねに柔軟に刘応で きる事業体制を整える。

\section{おわりに}

文化財庭園は、その地方の文化性を背景に造営され、 それぞれ特徵があり、まったく同じものは、存在しない。 そのため庭園修理も画一化できるものも少なく、マニュ アル化が難しい。今後、さらに情報安集め、マニュアル 作成に向け努力するつもりであるが、マニュアルの弊害 も忘れず取組んでいきたい。 


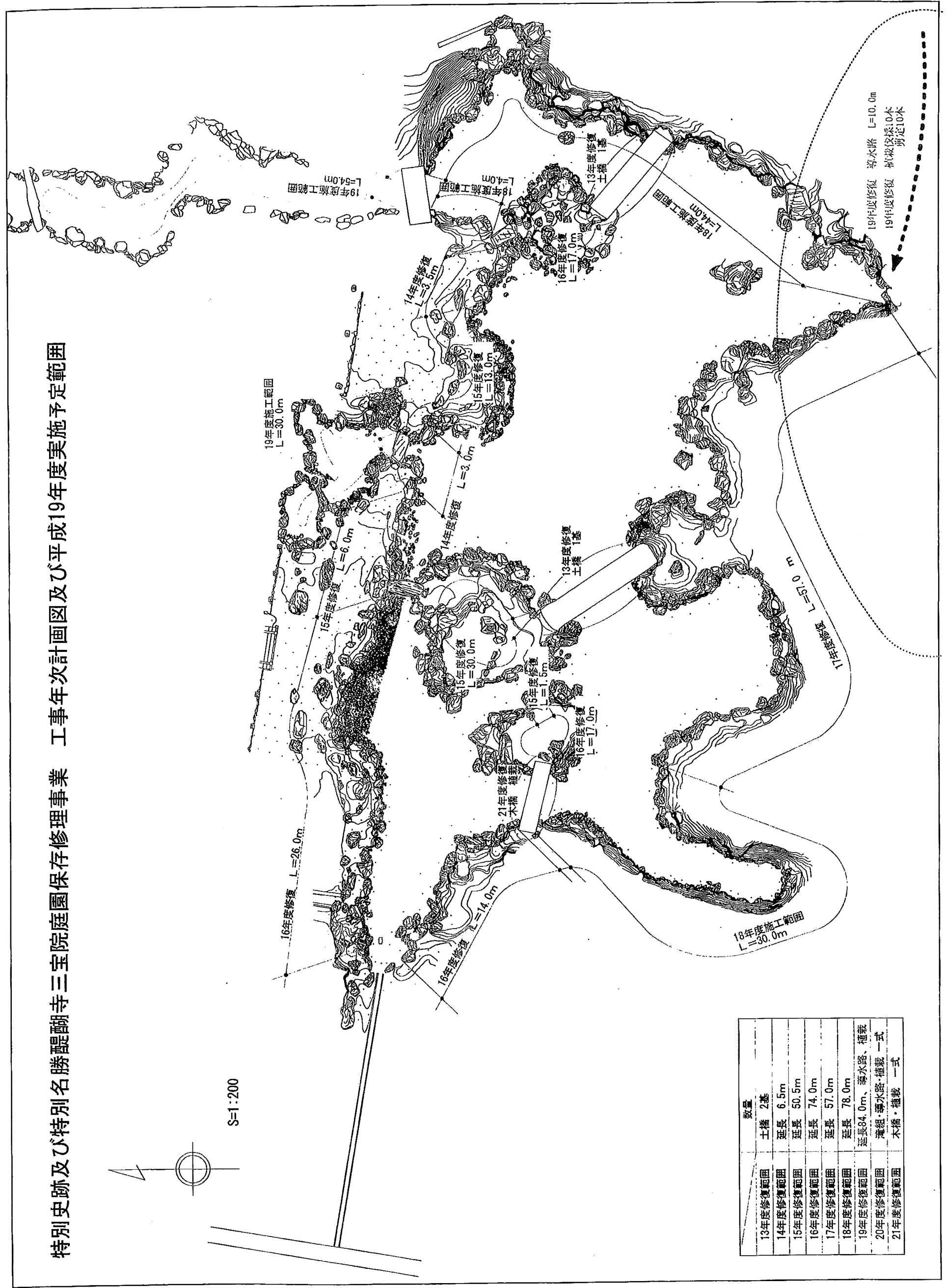

